\title{
IMPLEMENTASI PERATURAN MENTERI AGAMA NO. 46 TAHUN 2014 TENTANG BIAYA NIKAH LUAR KANTOR DI WILAYAH KABUPATEN PONOROGO
}

\author{
Muhammad Riza, Camila Karuniawati \\ Institut Agama Islam Riyadlatul Mujahidin Ngabar (IAIRM) Ponorogo \\ arabias671@gmail.com
}

\begin{abstract}
Regulation of the Minister of Religious Affairs No. 46 year 2014 governs the cost of marriage outside the office which is the prospective bride shall deposit the marriage fee or refer to the account of Treasurer amounting to Rp. 600,000, 00 (six hundred thousand Rupiah). The honorarium of the Penghulu is determined by the typology of the Office of Religious Affairs (KUA) of each region.In the region of Ponorogo Regency there are areas whose geographical conditions are easy to reach such as in the area of urban areas, and which is difficult to reach because it is located within the suburbs that have high enough plains, such as in the Office of Religious Affairs (KUA) subdistrict Pudak, Sooko and Ngrayun. From different geographical circumstances in Ponorogo District, the implementation of marriage and the determination of the cost of marriage in Ponorogo Regency is in accordance with the regulation of the Minister of Religious Affairs No. 46 year 2014 or not. This research uses field research method, which is the researcher plunging directly into the area of research, to obtain related data about the typologies of the Office of Religious Affairs (KUA) of the subdistrict of Pudak, Sooko and Ngrayun, the cost of marriage and the implementation of marriage outside the office in the region Ponorogo Regency. By using the field research, the results found that the implementation of marriage, especially in sub-district Pudak, Sooko and Ngrayun based on conditions and circumstances of the Community in accordance with the regulation of the Minister of Religious Affairs No. 46 year 2014. The determination of the marriage fee in the Office of Religious Affairs (KUA) of the district of Pudak, Sooko and Ngrayun Although the geographical condition is very different from the condition of the other region remains likened, namely Rp. 600,000, 00 (six hundred thousand Rupiah).
\end{abstract}

Keywords: Ministerial regulation No.46 yrs. 2014, Marriage fee.

\begin{abstract}
Abstrak
Peraturan Menteri Agama No. 46 tahun 2014 mengatur terkait biaya nikah luar kantor yaitu calon pengantin wajib menyetorkan biaya nikah atau rujuk ke rekening bendahara sebesar Rp.600.000,00 (enam ratus ribu rupiah). Adapun besaran honorarium penghulu ditentukan berdasarkan tipologi Kantor Urusan Agama (KUA) masing-masing wilayah.Di wilayah Kabupaten Ponorogo terdapat daerah-daerah yang kondisi geografisnya mudah untuk dijangkau seperti di daerah sekitar perkotaan, dan yang sulit untuk dijangkau karena berada dalam daerah pinggiran yang memiliki dataran yang cukup tinggi, seperti di Kantor Urusan Agama (KUA) Kecamatan Pudak, Sooko dan Ngrayun. Dari keadaan geografis yang berbeda-beda pada wilayah Kabupaten Ponorogo tersebut pelaksanaan nikah serta penentuan biaya nikah di wilayah Kabupaten Ponorogo apakah sudah sesuai dengan Peraturan Menteri Agama No. 46 tahun 2014 atau belum.Penelitian ini menggunakan metode penelitian lapangan (field research) yaitu peneliti terjun langsung ke daerah obyek penelitian, untuk memperoleh data yang berhubungan tentang tipologi Kantor Urusan Agama (KUA) Kecamatan Pudak, Sooko dan Ngrayun, biaya nikah dan pelaksanaan nikah luar kantor di wilayah Kabupaten Ponorogo. Dengan menggunakan metode (field research), hasil penelitian menemukan bahwa pelaksanaan nikah khususnya di Kecamatan Pudak, Sooko dan Ngrayun berdasarkan kondisi dan keadaan masyarakat kecamatan sesuai dengan Peraturan
\end{abstract}


Menteri Agama No. 46 tahun 2014. Penentuan biaya nikah di Kantor Urusan Agama (KUA) kecamatan Pudak, Sooko dan Ngrayun walaupun kondisi geografisnya sangat berbeda dengan kondisi wilayah yang lainya tetap disamakan, yaitu Rp.600.000,00 (enam ratus ribu rupiah).

Kata kunci: Permen No. 46 Thn. 2014, Biaya Nikah 


\section{A. PENDAHULUAN}

Undang-undang No. 1 tahun 1974 disebutkan bahwa perkawinan ialah ikatan lahir batin antara seorang pria dan seorang wanita sebagai suami isteri dengan tujuan membentuk keluarga (rumah tangga) yang bahagia dan kekal berdasarkan Ketuhanan Yang Maha Esa, dengan azas ini dapat diartikan bahwa perkawinan memiliki hubungan erat dengan agama. Karena itu perkawinan sah jika berdasarkan peraturan agama dan kepercayaan masing-masing para calon pengantin. ${ }^{1}$ Firman Allah dalam al-qur'an Surat al-Rum (30) ayat $21:^{2}$

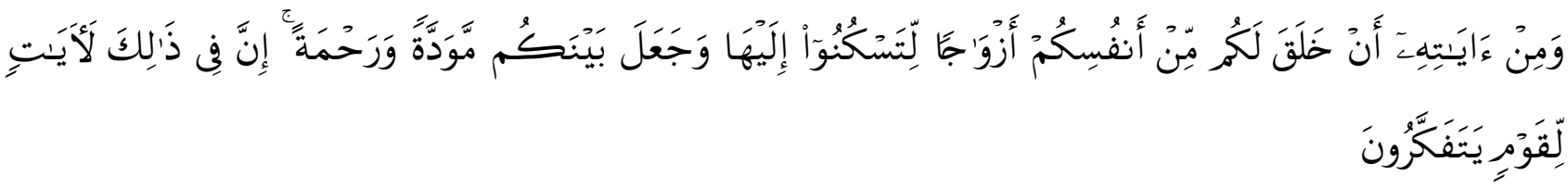

Artinya: Dan diantara tanda-tanda kekuasaan-nya ialah dia menciptakan untukmu istri-istri dari jenismu sendiri, supaya kamu cenderung dan merasa tentram kepadanya, dan jadikan-Nya diantaramu rasa kasih dan sayang. Sesungguhnya pada yang demikian itu benar-benar terdapat tanda-tanda bagi kaum yang berfikir. (QS. Al-Rum:21)

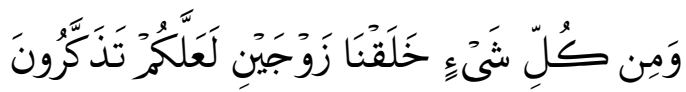

Artinya: Dan segala sesuatu kami ciptakan berpasang-pasangan supaya kamu mengingat kebesaran Allah. (Q.S Al-Dzariyat:49) ${ }^{3}$

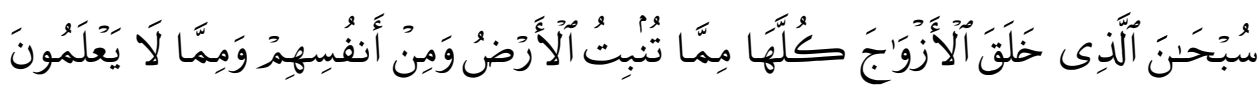

Artinya: Maha suci Tuhan yang telah menciptakan pasangan-pasangan semuanya, baik apa yang ditumbuhkan oleh bumi dan dari diri mereka maupun dari apa yang mereka tidak ketahui. ${ }^{4}$ (Q.S. Yasin:36)

Perkawinan merupakan salah satu peristiwa penting dalam kehidupan pribadi seseorang, dalam ruang lingkup yang lebih besar perkawinan merupakan proses awal dari pembentukan sebuah masyarakat. Bentuk dan corak masyarakat nantinya akan sangat ditentukan oleh warna keluarga yang dihasilkan melalui proses perkawinan, karena itu setiap perkawinan perlu diatur dan ditertibkan sedemikain rupa. Sehingga bisa menghasilkan keluarga yang baik dan bahagia, salah satu cara penertiban perkawinan ini adalah dengan cara pencatatan perkawinan oleh pejabat yang berwenang, yaitu Pegawai Pencatat Nikah (PPN). Sebagaimana terdapat dalam Kompilasi Hukum Islam (KHI) pasal 5 dan 6, pernikahan yang didaftarkan dan dicatat di Kantor Urusan Agama (KUA) akan mendapat perlindungan secara hukum dan yang paling penting dapat diselenggarakan dengan biaya yang murah. Selanjutnya bila perkawinan yang tidak dicatatkan dan dalam pengawasan pegawai pencatat nikah tidak akan memiliki kekuatan hukum. ${ }^{5}$

Berkenaan dengan penertiban perkawinan, di Indonesia sudah dibentuk pejabat atau badan yang khusus menangani masalah perkawinan yaitu Pegawai Pencatat Nikah (PPN) dan ini dalam naungan Kementerian Agama. PPN atau dikenal dengan sebutan penghulu diangkat langsung oleh Menteri Agama dan berada di setiap Kecamatan yang bertempat di Kantor Urusan Agama (KUA). PPN dalam menjalankan tugas khususnya dalam hal perkawinan diatur oleh Peraturan Menteri Agama (PMA) No. 11 tahun 2007 tentang Pencatatan Nikah. Oleh karena itu dalam menjalankan tugasnya PPN haruslah benar-benar serius dan proporsional.

Dalam Peraturan Pemerintah No. 47 tahun 2004 sudah diatur bahwa biaya nikah masuk dalam Pendapatan Negara Bukan Pajak (PNBP). Pasal 3 menyebutkan seluruh Penerimaan Negara Bukan

${ }^{1}$ Team Nusantara, Kitab Undang-undang Hukum Perdata (Burgerlijk Wetbook) (jakarta: Nusantara Publisher, 2009), 512.

${ }^{2}$ Al-Qur'an \& Tejemahannya, (Semarang: PT. Karya Putra, 1995), 644.

${ }^{3}$ H.S.A Al Hamdani, Risalah Nikah (Hukum Perkawinan Islam)(Jakarta: Pustaka Amani, 2002),1.

${ }^{4}$ Al-Qur'an \& Tejemahannya (Semarang: PT. Karya Putra, 1995)

${ }^{5}$ Abdurrahman, Kompilasi Hukum Islam di Jakarta (Jakarta: CV. Akademika Pressindo, 2010), 114. 
Pajak yang berlaku dalam Kementerian Agama wajib disetor langsung ke kas Negara. ${ }^{6}$ Sesuai Peraturan Menteri Agama Republik Indonesia No. 11 Tahun 2007 Tentang Pencatatan Nikah Pasal 21 Ayat 1, akad nikah dilaksanakan di KUA, sedangkan ayat 2, atas permintaan calon pengantin dan atas persetujuan Pegawai Pencatat Nikah (PPN), akad nikah dapat dilaksanakan di luar KUA. ${ }^{7}$ Atas dasar ayat 2 inilah hampir kebanyakan akad nikah dilaksanakan di luar KUA. Mengenai biaya pencatatan nikah dalam Peraturan Pemerintah No. 48 tahun 2014 menyebutkan bahwa biaya nikah di luar kantor KUA yaitu sebesar 600.000,00 (enam ratus ribu rupiah). ${ }^{8}$

Pada prinsipnya pernikahan adalah gratis jika dilaksanakan di KUA, sementara itu pencatatan di luar KUA dikenai biaya Rp 600.000. Menteri Agama menyatakan biaya itu untuk transportasi dan administrasi yang dikeluarkan penghulu saat menikahkan calon pengantin. Besaran biaya ini sama di seluruh Nusantara. Jika seorang penghulu menikahkan kedua calon pengantin dengan jarak yang cukup jauh dari kantor dan sulit untuk dijangkau karena alasan membutuhkan biaya transportasi itu bisa dikatakan hal yang wajar, tetapi akan jadi tidak wajar lagi jika biaya transportasi tidak terukur. Maka berangkat dari hal itu, biaya transport perlu ditentukan secara mendetail agar nantinya tidak terjadi pungutan liar. Mengenai biaya trasportasi PMA No. 46 Tahun 2014 telah menyebutkan bahwa:

a. Transport penghulu/petugas yang melaksanakan layanan dan bimbingan akad nikah di luar Kantor Urusan Agama Kecamatan diberikan per peristiwa dengan mengacu kepada ketentuan standart biaya masukan.

b. Transport penghulu/petugas yang melaksanakan beberapa layanan dan bimbingan akad nikah di satu waktu dan di tempat yang sama diberikan 1 (satu) kali transpor perjalanan.

c. Transport untuk perjalanan layanan dan bimbingan akad nikah pada KUA terdalam, terluar dan daerah perbatasan di daratan dihitung berdasarkan pengeluaran riil yang dapat dibuktikan dengan bukti pengeluaran dengan tiket perjalanan atau kwitansi transportasi maksimum Rp 750.000,00 (tujuh ratus lima puluh ribu rupiah).

d. Transport untuk perjalanan layanan dan bimbingan akad nikah pada KUA terdalam, terluar dan daerah perbatasan di kepulauan dihitung berdasarkan pengeluaran riil yang dapat dibuktikan dengan bukti pengeluaran dengan tiket perjalanan atau kwitansi transportasi maksimum Rp $1.000 .000,00$ (satu juta rupiah). ${ }^{9}$

Selain itu PMA No. 46 tahun 2014 juga membahas tentang tipologi KUA Kecamatan masingmasing wilayah yang ditetapkan oleh Kepala Kantor Wilayah Kementerian Agama Provinsi, dengan ketentuan sebagai berikut:

a. Tipologi A adalah KUA yang jumlah peristiwa nikahnya diatas 100 peristiwa dihitung rata-rata per bulan.

b. Tipologi B adalah KUA yang peristiwa nikahnya antara 50 s.d. 100 peristiwa dihitung rata-rata per bulan.

c. Tipologi $\mathrm{C}$ adalah KUA yang peristiwa nikahnya dibawah 50 peristiwa dihitung rata-rata per bulan.

d. Tipologi D adalah KUA yang secara geografis berada pada daerah terdalam, terluar dan daerah perbatasan di daratan.

e. Tipologi D1 adalah KUA yang secara geografis berada pada daerah terdalam, terluar dan daerah perbatasan di kepulauan. ${ }^{10}$

Berdasarkan yang telah tercantum di PMA No. 46 tahun 2014. Di wilayah Kabupaten Ponorogo juga terdapat daerah-daerah yang kondisi geografisnya mudah untuk dijangkau seperti di daerah sekitar perkotaan, dan yang sulit untuk dijangkau karena berada dalam daerah pinggiran

\footnotetext{
${ }^{6}$ Peraturan Pemerintah No. 47 Tahun 2004. Pdf, (diakses pada tanggal 18 September 2019, jam 20.45).

${ }^{7}$ Bidang Urusan Agama Islam Kantor Wilayah Departemen Agama Provinsi Jawa Timur, Himpunan Seputar Kepenghuluan (Surabaya: Departemen Agama Jawa Timur, 2007), 57.

${ }^{8}$ Peraturan Pemerintah No. 48 Tahun 2014. Pdf, (diakses pada tanggal 20 September 2019, Pukul 19.25 WIB).

${ }^{9}$ Keputusan Dirjen Bimbingan Masyarakat Islam No. 748 Tahun 2014 tentang PNBP, pdf, (diakses pada tanggal 19 September 2019, jam 19.30 WIB).

${ }^{10}$ Ibid.
} 
yang memiliki dataran yang cukup tinggi, misalkan di KUA Kecamatan Pudak, Sooko dan Ngrayun. Dari keadaan geografis yang berbeda-beda pada wilayah Kabupaten Ponorogo tersebut pelaksanaan nikah serta penentuan biaya nikah di wilayah Kabupaten Ponorogo apakah sudah sesuai dengan PMA No. 46 tahun 2014 atau belum.

\section{B. Pembahasan}

\section{Pelaksanaan perkawinan}

Islam sudah mengatur sedemikian rupa perihal perkawinan perkawinan bagi umat islam, begitupun juga Negara Indonesia terdapat peraturan khusus yang mengatur tentang perkawinan. Mulai dari syarat-syarat perkawinan sampai dengan administrasinya. Peraturan tersebut termuat dalam undang-undang No. 1 tahun 1974 tentang perkawinan dan Kompilasi Hukum Islam, selain itu sebagai pelaksana dari undang-undang tersebut dikeluarkan Peraturan Pemerintah No. 48 tahun 2014 tentang Tarif dan penerimaan Negara Bukan Pajaak (PNBP) pembaruan atas Peraturan Pemerintah No. 47 tahun 2004 tentang PNBP.

Selain itu juga ada Peraturan Menteri Agama No. 11 tahun 2007 tentang Pencatatan Nikah, Peraturan Menteri Agama No. 46 tahun 2014 tentang Pengelolaan Penerimaan Negara Bukan Pajak (PPNBP) atas Biaya Nikah atau Rujuk di Luar Kantor Urusan Agama Kecamatan perubahan atas peraturan Menteri Agama No. 24 tahun 2014. Kesemua peraturan tersebut akan dijelaskan lebih rinci sebagai berikut:

\section{Perkawinan Menurut Hukum Islam dan Undang-undang No. 1 tahun 1974}

Perkawinan merupakan hal yang sakral bagi setiap orang yang melakukannya, karena itu perlu diatur agar tidak terjadi kesewenang-wenangan terhadap hak dan kewajiban masing-masing baik suami atau istri supaya terpenuhi. Menurut hukum islam, pernikahan atau perkawinan adalah suatu ikatan lahir batin antara seorang laki-laki dengan seorang perempuan untuk hidup bersama dalam suatu rumah tangga dan untuk berketurunan yang dilaksanakan menurut ketentuan-ketentuan Syari'at Islam.

Pasal 1 Bab I Undang-undang No. 1 tahun 1974 tentang Perkawinan tanggal 2 Januari 1974 mengatur perkawinan ialah ikatan lahir batin antara seorang pria dengan seorang wanita sebagai suami istri dengan tujuan membentuk keluarga (rumah tangga) yang bahagia dan kekal berdasarkan Ketuhanan Yang Maha Esa. ${ }^{11}$

Hukum perkawinan merupakan bagian dari hukum Islam yang memuat ketentuan-ketentuan hal ihwal perkawinan yaitu proses prosedur menuju terbentuknya ikatan perkawinan, cara menyelenggarakan akad perkawinan menurut hukum, cara memelihara ikatan lahir batin yang telah diikrarkan dalam akad perkawinan sebagai akibat yuridis dari adanya akad itu, cara mengatasi krisis rumah tangga yang mengancam ikatan lahir batin antara suami istri, proses dan prosedur berakhirnya ikatan perkawinan, serta akibat yuridis dari berakhirnya perkawinan baik yang menyangkut hubungan hukum antara bekas suami dan istri, anak-anak dan harta mereka. ${ }^{12}$

Dari segi sosial, Perkawinan berkaitan dengan kedudukan atau strata sosial yang lebih dihargai dari pada mereka yang tidak menikah. Dari sudut pandang agama, Perkawinan merupakan suatu hal yang di pandang suci (sakral), sedangkan dari segi hukum, Perkawinan dipandang sebagai suatu perbuatan (peristiwa) hukum atau rechtsfeit, yakni perbuatan dan tingkah laku subyek hukum yang membawa akibat hukum. Karena hukum mempunyai kekuatan mengikat bagi subyek hukum atau karena subyek hukum itu terkait oleh kekuatan hukum. ${ }^{13}$

Seseorang yang bertempat di Indonesia, maka harus patuh dan tunduk terhadap peraturan dalam hal pelaksanaan perkawinan. Indonesia sudah membuat aturan sendiri yang mengatur masalah perkawinan sedemikian rupa, yakni Undang-undang No. 1 tahun 1974 tentang Perkawinan,

\footnotetext{
${ }^{11}$ Undang-Undang Nomor 1 tahun 1974 tentang Perkawinan, pdf (diakses tanggal 19 September 2019, Pukul 21.10 WIB).

${ }^{12}$ Zahry Hamid, pokok-pokok hukum perkawinan islam dan undang-undang perkawinan di Indonesia (Yogyakarta: Binacipta, 1976),01.

${ }^{13}$ Muhammad Amin Summa, Hukum Keluarga Islam di Dunia Islam (Jakarta: PT. Raja Grafindo Perkasa, 2004),69-81.
} 
Peraturan Pemerintah No. 48 tahun 2004 perubahan atas Peraturan Pemerintah No. 47 tahun 2004, PMA No. 11 tahun 2007 tentang Pencatatan Nikah dan Kompilasi Hukum Islam (KHI).

Perkawinan yang dilakukan atas dasar kesiapan mental, lahir dan batin oleh Undang-undang No. 1 tahun 1974 tentang Perkawinan dijadikan barometer akan sempurnanya sebuah cita-cita antara dua mempelai dalam membangun rumah tangganya. ${ }^{14}$ Sesuai dengan landasan falsafah negara Indonesia (Pancasila) dan Undang-undang dasar 1945, maka Undang-undang ini dapat mewujudkan prinsip-prinsip dalam Pancasila dan Undang-undang dasar 1945. Sedangkan dilain pihak harus dapat pula menampung segala kenyataan yang hidup dalam masyarakat.

Untuk menjamin kepastian hukum (yuridis), maka perkawinan segala sesuatu berhubungan dengan pernikahan sebelum Undang-undang berlaku. Menurut hukum positif tersebut sah, dari penjelasan umum undang-undang No. 1 tahun 1974 dapat ditarik kesimpulan bahwa bagi orang yang beragama Islam di Indonesia sahnya perkawinan dilakukan menurut hukum agamanya dan kepercayaan masing-masing, menurut Pasal 2 ayat (1) Undang-undang No. 1 tahun 1974. Syarat sahnya perkawinan menurut Undang-undang ini adalah:

a. Didasarkan atas persetujuan bebas antara calon suami dan calon istri, yang berarti tidak ada paksaan dalam perkawinan.

b. Pada azasnya perkawinan itu adalah satu istri bagi satu suami (monogami) dan begitupun sebaliknya kecuali mendapat izin dari pengadilan agama dengan berbagai syarat-syarat berat.

c. Pria harus telah berumur 19 (sembilan belas) tahun dan wanita 16 (enam belas) tahun.

d. Harus mendaptkan izin masing-masing dari kedua orang tua mereka kecuali dalam hal-hal tertentu dan calon pengantin telah berusia 21 (dua puluh satu) tahun atau lebih, atau mendapat dispensasi dari Pengadilan Agama apabila umur para calon dari ketentuan yang ada.

e. Tidak termasuk dalam larangan-larangan perkawinan atara keduanya.

f. Seorang yang masih terkait perkawinan dengan orang lain kecuali dispensasi oleh pengadilan.

g. Seorang yang telah cerai untuk kedua kalinya maka diantara mereka tidak boleh dilangsungkan perkawinan lagi sepanjang hukum masing-masing agama dan kepercayaanya itu dari yang bersangkutan tidak menentukan lain.

h. Seorang wanita yang perkawinannya terputus untuk kawin lagi telah lampau tenggang waktu tunggu.

i. Perkawinan harus dilangsungkan menurut tata cara perkawinan yang diatur oleh Peraturan Pemerintah No. 9 tahun 1975 jo Peraturan Menteri Agama No. 3 tahun 1975 tentang Pencatatan Nikah, Talak dan Rujuk. ${ }^{15}$ Yang sekarang diperbaharui menjadi Peraturan Pemerintah No. 48 tahun 2004 perubahan atas Peraturan Pemerintah No. 47 tahun 2004 jo Peraturan Menteri Agama No. 11 tahun 2007 tentang Pencatatan Nikah.

Undang-undang No. 1 tahun 1974 tentang Perkawinan dijadikan sebagai dasar dan pijakan bagi pelaksanaan perkawinan di Indonesia, ditambah dengan Peraturan Pemerintah No. 48 tahun 2004 perubahan atas Peraturan Pemerintah No. 47 tahun 2004 sebagai pelaksana dari Undangundang tersebut. Selain itu khusus bagi umat islam terdapat juga Kompilasi Hukum Islam (KHI) yang mengatur masalah Perkawinan, Waris dan Wakaf.

Undang-undang tersebut diharapkan agar tertib administrasi Negara, agar perkawinan terlaksana dengan baik sesuai dengan agama dan kepercayaan masing-masing, serta mendapatkan pengakuan dari Negara dan mendapatkan kepastian hukum. Seperti yang telah tertera diatas bahwa dijelaskan hal ihwal yang menjadi pembahasan dalam hal perkawinan mulai dari proses dan prosedur dari perkawinan sampai dengan bagaimana menjaga agar perkawinan tersebut dapat dibina dengan baik agar tercapai tujuan menjadi keluarga bahagia dan kekal. Akan tetapi dalam hal ini terbatasi hanya pada pelaksanaan perkawinan yang diatur menurut Undang-Undang perkawinan No. 1 tahun 1974 tentang perkawinan.

Undang-Undang perkawinan tidak mengatur secara lengkap bagaimana pelaksanaan perkawinan itu, tetapi Undang-Undang tersebut mengatur secara global perkawinan seperti yang

${ }^{14}$ Bani Ahmad Saebani, Perkawinan Dalam Hukum Islam dan Undang-undang (bandung: Pustaka Setia, 2008), 18.

\footnotetext{
${ }^{15}$ Mohd. Idris Ramulyo, Hukum Perkawinan Islam (Jakarta: Bumi Aksara, 1999), 55-59.
} 
tertata pada Pasal 2 ayat (1) yang menyatakan perkawinan dianggap sah apabila dilaksanakan menurut agamanya dan kepercayaannya masing-masing. Dapat ditarik kesimpulan untuk melaksanakan perkawinan secara lebih lengkapnya dikembalikan kepada agama dan kepercayaan setiap orang masing-masing yang akan melaksanakan perkawinan. Karena Indonesia adalah Negara pluralis dengan berbagai agama, maka Undang-Undang ini sifatnya mengayomi seluruh elemen masyarakat. Dan yang terpenting dalam Undang-Undang ini perkawinan sah ketika dicatatkan sehingga memiliki kekuatan hukum.

\section{Perkawinan Menurut Kompilasi Hukum Islam (KHI)}

Melihat dari sisi historinya Kompilasi Hukum Islam (KHI) merupakan ijma' para ulama Indonesia yang terintis sejak Indonesia merdeka, dalam lokakarya yang diadakan di Jakarta pada tanggal 2-5 Februari 1988. Para ulama Indonesia sepakat menerima tiga rancangan buku Kompilasi Hukum Islam yaitu, buku I tentang Hukum Perwakafan. Kompilasi Hukum Islam diharapkan dapat digunakan oleh instansi pemerintah dan masyarakat dalam menyelesaikan masalah-masalah hukum islam yang diharapkannya. ${ }^{16}$

KHI terdapat 3 (tiga) pembahasan penting, yakni tentang perkawinan, wakaf, dan waris. Akan tetapi supaya lebih fokus akan dipaparkan tentang masalah perkawinan terlebih dalam hal pelaksanaannya, karena KHI memang diperuntukan bagi orang Islam saja sehingga pelaksanaan perkawinan perlu diatur sedemikian rupa.

Perkawinan menurut hukum Islam bukan semata-mata hubungan atau kontrak keperdataan biasa, tetapi mempunyai nilai ibadah. ${ }^{17}$ Sebagaimana tercantum dalam Kompilasi Hukum Islam pengertian perkawinan dan tujuannya dinyatakan dalam pasal 2 dan 3 yang bunyinya sebagai berikut: pasal 2 berbunyi perkawinan menurut hukum Islam adalah pernikahan, yaitu akad yang sangat kuat atau mitsaqan ghalizhan untuk menaati perintah Allah dan melaksanakannya merupakan ibadah. Sedangkan dalam pasal 3 berbunyi perkawinan bertujuan untuk mewujudkan kehidupan rumah tangga yang sakinah, mawaddah, dan rahmah.

Sayyid Sabiq, lebih lanjut mengomentari perkawinan merupakan salah satu sunnatullah yang berlaku pada semua makhluk Tuhan baik manusia, hewan maupun tumbuhan. Perkawinan merupakan salah satu cara yang dipilih Allah sebagai jalan bagi manusia untuk beranak-pinak, berkembang biak dan melestarikan hidupnya setelah masing-masing melakukan peranya yang positif dalam mewujudkan tujuan perkawinan. Demi menjaga kehormatan dan martabat kemuliaan manusia Allah mengadakan hukum sesuai dengan martabatnya, sehingga hubungan antara laki-laki dan perempuan diatur secara terhormat dan berdasarkan saling meridhoi.

Bentuk perkawinan seperti ini telah memberikan jalan yang aman pada naluri batiniah, memelihara keturunan dengan baik dan menjaga kaum perempuan agar tidak seperti laksana rumput yang bisa dimakan oleh binatang ternak dengan seenaknya. ${ }^{18}$ Pada dasarnya apa yang termuat dalam KHI yang berhubungan dengan perkawinan semuanya telah termuat dalam Undang-undang No. 1 tahun 1974 tentang Perkawinan jo Peraturan Pemerintah No. 9 tahun 1975 tentang Pelaksanaan Undang-undang. Hanya saja dalam KHI muatanya lebih terperinci, larangan lebih dipertegas dan menambah beberapa poin sebagai aplikasi dari peraturan perundang-undangan yang telah ada.

Perkawinan akan sah apabila dilakukan menurut hukum islam dan ini sesuai dengan ketentuan dalam pasal 2 ayat (1) Undang-undang No. 1 tahun 1974 tentang perkawinan. Di dalam undangundang tersebut sebenarnya juga sudah terdapat ketentuan bahwa perkawinan harus dicatatkanm, begitu juga dengan KHI pasal 5 ayat (2) memerintahkan agar perkawinan dicatatkan dengan tujuan agar terjamin ketertiban bagi masyarakat islam. Pencatatan perkawinan yang dimaksud dilakukan oleh Pegawai Pencatat Nikah (PPN) sebagaimana diatur Undang-undang No. 22 tahun 1946 jo Undang-undang No. 32 tahun 1954.

\footnotetext{
${ }^{16}$ Abdul Manan, Aneka Masalah Hukum Perdata Islam di Indonesia (Jakarta: Kencana Prenada Media Group, 2006), 26.

${ }^{17}$ Beni Ahmad Saebani dan Syamsul Falah, Hukum Perdata Islam di Indonesia (Bandung: CV. Pustaka Setia, 2011), 105.

${ }^{18}$ Abd. Rahman Ghazaly, Fiqh Munakahad (Jakarta: Kencana Prenada Media, 2003), 10-11.
} 
Perkawinan sah menurut KHI harus dilangsungkan dihadapan dan di bawah pengawasan PPN dengan tujuan agar mempunyai kekuatan hukum. Sebaliknya perkawinan yang tidak dilangsungkan di hadapan dan di bawah pengawasan PPN tidak mempunyai kekuatan hukum. Karena ketika perkawinan tersebut dilangsungkan di hadapan PPN nantinya akan diterbitkan akta nikah sebagai bukti konkrit bahwa perkawinan tersebut benar-benar dilaksanakan. ${ }^{19}$

Perkawinan menurut KHI tidak jauh berbeda dengan Undang-undang No. 1 tahun 1974, hanya dalam KHI lebih melengkapi dan merinci mulai dari proses awal perkawinan, permasalahan dengan perkawinan dan juga perceraian atau putusnya perkawinan.

\section{Perkawinan Menurut Peraturan Menteri Agama No. 11 tahun 2007 dan Peraturan}

Pemerintah No. 48 tahun 2004 perubahan atas PP No. 47 tahun 2004

Kelahiran Peraturan Menteri Agama No. 11 tahun 2007 tanggal 21 juli 2007 tentang Pencatatan Nikah cukup mengundang perhatian terutama di kalangan pelaksana undang-undang perkawinan, PMA No. 11 tahun 2007 ini membatalkan Keputusan Menteri Agama (KMA) No. 447 tahun 2004 tentang perihal yang sama. Padahal lahirnya KMA No. 447 tahun 2004 merupakan upaya realisasi dari sebuah gagasan besar. ${ }^{20} \mathrm{KMA}$ ini mengemban amanat untuk mewujudkan sebuah konsep yng sudah sangat lama direncanakan guna mencapai cita-cita yang luhur dan strategis, yaitu terberdayanya KUA dalam berbagai aspek tugas pokok dan fungsinya. Supaya KUA kedepan tidak hanya dalam lingkup tugas nikah, talak, cerai, rujuk (NTCR). Akan tetapi, tampaknya para pembuat kebijkan dalam merumuskan PMA No. 11 tahun 2007 mempunyai pertimbangan dan Planning lain, yang dianggap lebih cerdas dan progressif demi kebaikan dan kemajuan KUA itu sendiri sebagai lini terdepan Kementerian Agama. ${ }^{21}$

Peraturan Menteri Agama tersebut diterbitkan untuk lebih mempertegas betapa pentingnya sebuah perkawinan dalam hidup manusia karena termasuk kebutuhan biologis manusia. Karena pentingnya tersebut maka perlu diatur, terkhusus pada pelaksanaan akad nikah sudah disebutkan dengan jelas di dalam Pasal 21 ayat (1) dan ayat (2). Ayat (1) disebutkan bahwa perkawinan dilaksanakan di Kantor Urusan Agama (KUA). Sedangkan ayat (2) menyebutkan bahwa atas permintaan pengantin dan atas persetujuan PPN, akad nikah dapat dilaksanakan di luar KUA. Hal ini mencerminkan bahwa masyarakat diberi pilihan dengan memilih untuk melaksanakan perkawinan di KUA atau di luar KUA dengan persetujuan PPN.

Peraturan Menteri Agama No. 11 tahun 2007 ini menjadi dasar atau pijakan bagi para Penghulu dalam hal melaksanakan tugasnya melayani masyarakat yang akan menikah, jika merujuk pada PMA ini tidak ada hal yang dipermasalahkan. PPN bertugas sebagai pencatat atau orang yang melaksanakan administrasi pernikahan baik berkaitan dengan berkas-berkas nikah maupun dengan biaya nikah sudah sesuai dengan aturan yang ada.

Ketika perkawinan ditertibkan supaya memiliki kekuatan hukum tentunya membutuhkan biaya administrasi. Supaya tertib administrasi biaya perkawinan diatur dalam Peraturan Pemerintah No. 48 tahun 2004 perubahan atas PP No. 47 tahun 2004 tentang Tarif dan Jenis Penerimaan Negara Bukan Pajak. Peraturan Pemerintah ini mengatur bahwa tarif biaya nikah adalah Rp 600.000,- dan biaya tersebut langsung masuk kas Negara. Dengan adanya peraturan-peraturan tersebut diharapkan supaya tertib administrasi Negara karena Indonesia adalah Negara hukum, maka harus ada hukum yang mengatur seluruh warga negaranya. ${ }^{22}$

Pasca terbitnya Peraturan Pemerintah No. 48 Tahun 2014 kembali muncul Peraturan Menteri Agama No. 24 Tahun 2014 tentang Pengelolaan Penerimaan Negara Bukan Pajak atas Biaya Nikah dan Rujuk di luar Kantor Urusan Agama yang diterbitkan pada tanggal 13 Agustus 2014. PMA 24 tahun 2014 ini merevisi aturan sebelumnya yaitu PMA No. 71 Tahun 2009 tentang Pengelolaan Biaya Pencatatan Nikah dan rujuk yang sudah tidak sesuai lagi pasca terbitnya PP No. 48 Tahun 2014 yang merevisi PP No.47 Tahun 2004 (pasal 23). Dalam aturan tersebut dijelaskan bahwa

${ }^{19}$ Ibid., 1-2.

${ }^{20}$ Eko Mardion, “kritik terhadap penerapan hukum PMA no. 11 tahun 2007”, dalam ekomardiono.blogspot.com (diakses tanggal 20 September 2019 pukul 22. 14 WIB).

${ }^{21}$ Ibid.

${ }^{22}$ Bimasislam.kemenag.go.id/post/opini/pp-48-2014, diakses tgl. 25 September 2019, Pukul 10.25 wib. 
dalam mekanisme penyetoran, calon pengantin wajib menyetorkan biaya nikah/rujuk ke Rekening bendahara penerimaan sebesar Rp 600.000 pada Bank, namun apabila kondisi geografis, jarak tempuh atau tidak terdapat layanan bank pada wilayah kecamatan tersebut maka calon pengantin dapat menyetorkan biaya nikah atau rujuknya kepada PPS (Petugas Penerima Setoran) pada KUA yang telah ditunjuk berdasarkan SK dari Kepala Kemenag Kabupaten (pasal 6). ${ }^{23}$

Adapun penggunaan kembali biaya tersebut pada pasal 11 dijelaskan untuk pembiayaan transport dan jasa profesi penghulu, pembantu PPN, pengelola PNBP Biaya NR, Kursus Pra Nikah dan Supervisi Administrasi NR. Hingga saat ini besaran biaya transportasi dan jasa profesi masih menunggu Peraturan Menteri Keuangan dan Edaran Direktur Jendral Bimas Islam.

Adapun pelaksanaan Nikah di KUA pada jam dan hari kerja belum diatur dalam aturan apapun sehingga beberapa prosedur dan tata cara pelaksanaannya masih beragam dan menurut hemat penulis semestinya juga diatur dalam aturan tersendiri sebagaimana PMA ini juga mengatur tentang ketentuan bagi masyarakat yang tidak mampu dan korban bencana yang menghendaki nikah di luar kantor dengan biaya Rp 0,00. yang diatur dalam pasal 19.

Cara penerimaan di dalam PMA Nomor 71 Tahun 2009 BAB II Pasal 1 ayat (1) calon pengantin membayar biaya NR kepada Bendahara penerimaan pada Kandepag melalui bendahara pembantu pada KUA. Di dalam PMA Nomor 24 Tahun 2014 BAB III Pasal 6 ayat (1) Catin wajib menyetorkan biaya nikah atau rujuk ke renening Bendahara Penerimaan sebesar Rp 600,000,- pada Bank. Pada ayat (2) Apabila kondisi geografis, jarak tempuh, atau tidak terdapat layanan Bank pada wilayah kecamatan setempat, catin menyetorkan biaya nikah atau rujuk sebagaimana dimaksud pada ayat (1) melalui PPS pada KUA Kecamatan. ayat (2):

Penggunaan biaya Nikah Rujuk pada PMA Nomor 71 Tahun 2009 ada pada BAB IV Pasal 5

a. Peningkatan SDM dalam rangka meningkatkan kualitas pelayanan NR kepada masyarakat.

b. Pelayanan dan bimbingan di bidang perkawinan serta penegakan hukum.

c. Investasi yang berkaitan dengan kegiatan NR.

d. Pemeliharaan, perbaikan kantor, gedung dan investasi lainnya lainnya ang berkaitan dengan pelayanan NR.

e. Operasional perkantoran dalam rangka meningkatkan pelayanan NR serta transport Penghulu, pegawai dan Pembantu Pegawai Pencatat Nikah (P3N).

Ayat (3) Penggunaan PNBP NR dalam kegiatan sebagaimana dimaksud pada ayat (2) dituangkan dalam RKA-KL dengan porsi sebagai berikut:

a. Kandepag Kab/Kota sebesar $20 \%$ dari Pagu Pengeluaran.

b. KUA sebesar $80 \%$ dari Pagu Pengeluaran.

Sedangkan di dalam PMA Nomor 24 Tahun 2014 penggunaan PNBP itu tercantum di dalam pasal 11 ayat (1) PNBP Biaya NR digunakan untuk membiayai pelayanan pencatatan nikah dan rujuk yang meliputi:

a. Transport dan jasa profesi penghulu.

b. Pembantu Pegawai Pencatat Nikah.

c. Pengelola PNBP Biaya NR.

d. Kursus pra nikah.

e. Supervisi administrasi nikah dan rujuk.

Sedangkan ayat (2) Penggunaan PNBP Biaya NR sebagaimana dimaksud pada ayat (1) dengan ketentuan:

a. Transport dan jasa profesi penghulu diberikan sesuai dengan Tipologi KUA Kecamatan.

b. Pembantu Pegawai Pencatat Nikah diberikan biaya pelayanan setiap bulan.

c. Pengelola PNBP Biaya NR diberikan biaya pengelolaan setiap bulan.

d. Kursus pra nikah, supervise administrasi nikah dan rujuk diberikan biaya setiap kegiatan.

Dalam Pasal 12 besaran transport dan jasa Profesi penghulu, biaya pelayanan pembantu pegawai pencatat nikah, pengelola PNBP biaya NR, Kursus pra nikah, supervisi administrasi nikah 
dan rujuk sebagaimana dimaksud dalam pasal 11 ditetapkan oleh Direktur Jenderal. Perubahan penggunaan PNBP ini sangat besar. Di antaranya yaitu:

a. Memperjelas penerimaan transportasi dan jasa profesi penghulu, sebagai bentuk kompensasi dan penghargaan Penghulu yang melaksanakan tugas di luar jam kantor atau di luar kantor.

b. Memperjelas insentif pelayanan P3N.

c. Memperjelas penerimaan bagi pengelola dari tingkat pusat sampai tingkat KUA, sebagai berikut:

1. Pusat: a) Penanggungjawab, b) Ketua dan Wakil ketua, c) Sekretaris dan wakil sekretaris, d) koordinator bidang perencanaan PNBP Biaya NR, e) Koordinator bidang Penerimaan PNBP NR, f) Koordinator bidang penggunaan PNBP NR, g) Pelaksana. (PMA No. 24 Tahun 2014 pasal 3 ayat (2)).

2. Pengelola Tingkat Daerah: a) Kabid Urais pada kanwil kemenag sebagai penanggung jawab dan 1 (satu) orang pelaksana administrasi. b) Kasi Urais pada Kemenag Kabupaten/kota sebagai penanggungjawab dan 1 (satu) orang pelaksana administrasi; dan c) Kepala KUA Kecamatan sebagai penanggungjawab dan 1 (satu) orang pelaksana administrasi. (PMA No. 24 Tahun 2014 pasal 3 ayat (4).

d. Memfungsikan dan menggiatkan kembali Kursus pra nikah.

e. Adanya kejelasan biaya operasional bagi kegiatan supervisi administarasi NR.

Dalam hal ini, ada perbedaan jelas antara penggunaan di dalam PMA No. 24 Tahun 2014 dan PMA No. 71 Tahun 2009. Di dalam PMA No. 71 Tahun 2009 penggunaannya menggunakan bahasa yang sangat umum dan masih multi tafsir, sehingga penggunaannya sangat fleksibel bahkan kadang menjadi bias. Akan tetapi di dalam PMA No. 24 Tahun 2014 penggunaannya menggunakan bahasa yang sangat jelas dan lugas tanpa multi tafsir, bahwa ada 5 pos penggunaan anggaran PNBP, yaitu: Penghulu, P3N, Pengelola PNBP, Kegiatan Kursus Pra Nikah, dan Supervisi Administrasi NR oleh Seksi Bimas Islam Kemenag tingkat Kabupaten/Kota.

\section{5. $\quad$ Keputusan Dirjen Bimas Islam No. 748 tahun 2014}

Bahwa untuk mewujudkan tata kelola PNBP atas biaya NR yang baik dibutuhkan berbagai regulasi yang dapat dijadikan pedoman dalam pelaksanaannya. Seiring dengan hal tersebut dan dalam rangka menindaklanjuti Peraturan Pemerintah No. 48 tahun 2014 tentang perubahan atas Peraturan Pemerintah No. 47 tahun 2014 tentang tarif atas jenis Penerimaan Negara Bukan Pajak (PNBP) yang berlaku pada Departemen Agama dan Peraturan Menteri Agama No. 46 tahun 2014 tentang Pengelolaan Penerimaan Negara Bukan Pajak atas Biaya Nikah atau Rujuk di luar Kantor Urusan Agama Kecamatan, perlu menerbitkan Keputusan Direktur Jenderal Bimbingan Masyarakat Islam tentang Biaya Nikah atau Rujuk di luar Kantor Urusan Agama Kecamatan.

Petunjuk teknis Pengelolaan Penerimaan Negara Bikan Pajak atas Biaya Nikah atau Rujuk di Kantor Urusan Agama Kecamatan meliputi: Tugas pengelola PNBP Biaya Nikah atau Rujuk Pusat dan Daerah. Ini sudah terangkum dalam bab II, Mekanisme penerimaan, pencairan dan penggunaan, yang terangkum dalam bab III, Tipologi Kantor Urusan Agama Kecamatan, yang terangkum dalam bab IV, Pelaporan dan pertanggungjawaban, yang terangkum dalam bab V. ${ }^{24}$

\section{Peraturan Menteri Agama No. 46 tahun 2014}

PMA ini terdiri dari 9 bab, bab I Ketentuan Umum, bab II Struktur Pengelola, Dalam bab III tentang mekanisme pengelolaan PNBP NR, bagian kesatu yaitu Penyetoran, Penerimaan, Pencaiaran sebagai berikut:

Dalam pasal 9 Peraturan Menteri Agama No 46 tahun 2014:

a. Catin wajib menyetorkan biaya nikah atau rujuk ke rekening bendahara. Penerimaan pada Bank penerima setoran sebesar Rp 600.000,00 (enam ratus ribu rupiah).

\footnotetext{
${ }^{24}$ Bimasislam.kemenag.go.id/post/opini/pp-48-2014, diakses tgl. 25 September 2019, Pukul 10.25
}

wib. 
b. Apabila kondisi geografis, jarak tempuh, atau tidak terdapat layanan Bank pada wilayah kecamatan setempat, catin menyetorkan biaya nikah atau rujuk sebagaimana yang dimaksud pada ayat (1) melalui PPS pada KUA Kecamatan.

c. PPS sebagaimana dimaksud pada ayat (2) wajib menyetorkan biaya nikah atau rujuk ke rekening Bendahara Penerima paling lambat lima (5) hari kerja.

d. Dalam hal penyetoran sebagaimana dimaksud pada ayat (3) tidak dapat dilakukan, maka penyetorannya dilakukan setelah mendapat izin dari Kantor Wilayah Direktorat Jenderal Perbendaharaan setempat.

e. Dalam hal nikah atau rujuk dilaksanakan di luar negeri, biaya nikah atau rujuk disetorkan ke rekening Bendahara Penerima.

Sedangkan dalam Pasal 10 Peraturan Menteri Agama yaitu:

1) Bank penerima setoran sebagaimana dimaksud pada Pasal 9 ayat (1) wajib menerbitkan bukti setoran berupa slip setoran atas setoran biaya nikah atau rujuk yang diterima dari catin.

2) Slip setoran sebagaimana dimaksud pada ayat (1), meliputi:

a) Identitas Bank. b) Tanggal penyetoran. c) Nomor rekening yang dituju. d) Jumlah uang. e) Nama penyetor. f) Nama catin pria dan wanita, g) Alamat catin, h) Nama/kode KUA Kecamatan, i)Nama/kode Kabupaten/Kota, j) Nama/kode provinsi, k) Pengesahan petugas Bank, 1) Tanda tangan penyetor.

3) Slip setoran sebagaimana dimaksud pada ayat (2) dibuat rangkap 3 (tiga) diperuntukkan:

a) Lembar pertama untuk Bank

b) Lembar kedua untuk catin

c) Lembar ketiga untuk KUA Kecamatan

Sedangkan dalam bab IV terkait dengan tipologi KUA Kecamatan, yaitu terdiri dari Pasal 18 berbunyi, tipologi KUA Kecamatan ditentukan menurut jumlah peristiwa nikah atau rujuk perbulan dan kondisi geografis keberadaan KUA Kecamatan. Sedangkan Pasal 19 adalah sebagai berikut:

a. Tipologi A adalah KUA yang jumlah peristiwa nikahnya diatas 100 peristiwa dihitung rata-rata per bulan.

b. Tipologi B adalah KUA yang peristiwa nikahnya antara 50 s.d. 100 peristiwa dihitung rata-rata per bulan.

c. Tipologi $\mathrm{C}$ adalah KUA yang peristiwa nikahnya dibawah 50 peristiwa dihitung rata-rata per bulan.

d. Tipologi D adalah KUA yang secara geografis berada pada daerah terdalam, terluar dan daerah perbatasan di daratan.

e. Tipologi D1 adalah KUA yang secara geografis berada pada daerah terdalam, terluar dan daerah perbatasan di kepulauan.

Selanjutnya bab V tentang Perangkat Pencairan, bab VI terkait dengan Pelaporan, bab VII yaitu syarat dan tata cara dikenakan tarif Rp. 0,00 (nol rupiah), bab VIII terkait dengan Supervisi dan bab IX tentang Ketentuan Penutup.

Selanjutmya terkait dengan ketentuan-ketentuan biaya tipologi di atas yaitu terdapat dalam Keputusan Direktorat Jenderal Bimbingan Masyarakat Islam (Bimas Islam) No. 748 tahun 2014, Bab III tentang Pencairan, Penerimaan dan Penggunaan.

\section{Pelaksanaan Perkawinan di Kecamatan Pudak, Sooko dan Ngrayun Kabupaten Ponorogo Setelah Diberlakukannya PMA No. 46 tahun 2014}

Sejak diberlakukan dan disosialisasikan PMA No. 46 tahun 2014 dan Peraturan Pemerintah No. 48 tahun 2014 tentang Tarif dan penerimaan Negara Bukan Pajaak (PNBP) pembaruan atas Peraturan Pemerintah No. 47 tahun 2004 tentang PNBP, yang di dalamnya dijelaskan bahwa nikah yang dilaksanakan di Kantor Urusan Agama (KUA) dikenakan biaya Rp 0,00 (nol rupiah) sedangkan nikah yang dilaksanakan di luar Kantor Urusan Agama (KUA) dikenakan biaya Rp 600.000,00 (enam ratus ribu rupiah). Namun kenyataannya masih ada calon pengantin yang melaksanakan nikah di luar Kantor Urusan Agama (KUA).

Menurut keterangan kepala KUA Kecamatan Pudak, Sooko dan Ngrayun menerangkan bahwa pelaksanaan perkawinan di wilayah Kecamatan Pudak, Sooko dan Ngrayun sudah terlaksana 
dengan baik sesuai dengan kondisi masyarakat di kecamatan tersebut. Di wilayah Kecamatan Pudak, Sooko dan Ngrayun rata-rata pernikahan dilaksanakan banyak yang di kantor, untuk prosentse luar kantor sekitar 25\%. Sedangkan untuk sosialisasi terkait dengan Peraturan Menteri Agama ini melalui petugas yang ada disetiap desa (Modin).

\section{Penentuan Biaya Nikah di KUA Kecamatan Pudak, Sooko dan Ngrayun Kabupaten Ponorogo}

Peraturan Menteri Agama No. 11 tahun 2007 menjadi dasar atau pijakan bagi para Penghulu dalam hal melaksanakan tugasnya melayani masyarakat yang akan menikah, jika merujuk pada PMA ini tidak ada hal yang dipermasalahkan. PPN bertugas sebagai pencatat atau orang yang melaksanakan administrasi pernikahan baik berkaitan dengan berkas-berkas nikah maupun dengan biaya nikah sudah sesuai dengan aturan yang ada. Ketika perkawinan ditertibkan supaya memiliki kekuatan hukum tentunya membutuhkan biaya administrasi. Supaya tertib administrasi biaya perkawinan diatur dalam Peraturan Pemerintah No. 48 tahun 2004 perubahan atas PP No. 47 tahun 2004 tentang Tarif dan Jenis Penerimaan Negara Bukan Pajak. Peraturan Pemerintah ini mengatur bahwa tarif biaya nikah adalah Rp 600.000,- dan biaya tersebut langsung masuk kas Negara. Dengan adanya peraturan-peraturan tersebut diharapkan supaya tertib administrasi Negara karena Indonesia adalah Negara hukum, maka harus ada hukum yang mengatur seluruh warga negaranya. ${ }^{25}$ Penentuan biaya nikah di wilayah Kecamatan Pudak, Sooko dan Ngrayun yaitu sebesar Rp 600.000,00 (enam ratus ribu rupiah). Untuk ketentuan biaya $\mathrm{Rp}$ 600.000,00 tersebut sudah termasuk dengan biaya honorarium penghulu, jadi sesuai dengan ketentuan tersebut misalkan satu hari ada lima kali peristiwa pernikahan maka biaya honorarium penghulu tersebut dianggap 1 kali peristiwa.

Meskipun secara geografis KUA Kecamatan Pudak, Sooko dan ngrayun memang terletak di dataran tinggi atau bisa dikatakan daerah pegunungan dan medan yang sulit untuk dilewati, akan tetapi dalam ketentuan biaya nikah itu disamakan dengan KUA yang berada di daerah-daerah yang datar atau mudah di jangkau. Peraturan Menteri Agama No. 46 tahun 2014 Pasal 19 yang menjelaskan mengenai keadaan tipologi suatu daerah sebagai berikut :

a. Tipologi A adalah KUA yang jumlah peristiwa nikahnya diatas 100 peristiwa dihitung rata-rata per bulan.

b. Tipologi B adalah KUA yang peristiwa nikahnya antara 50 s.d. 100 peristiwa dihitung rata-rata per bulan.

c. Tipologi $\mathrm{C}$ adalah KUA yang peristiwa nikahnya dibawah 50 peristiwa dihitung rata-rata per bulan.

d. Tipologi D adalah KUA yang secara geografis berada pada daerah terdalam, terluar dan daerah perbatasan di daratan.

e. Tipologi D1 adalah KUA yang secara geografis berada pada daerah terdalam, terluar dan daerah perbatasan di kepulauan.

Ketentuan tipologi KUA ini masih menjadi kontroversi antara KUA yang berada dalam kondisi geografisnya lebih tinggi, medan sulit dilalui dan tempat yang jauh dengan KUA yang berada dalam kondisi wilayah normal atau kondisi daratan yang rata dan mudah dijangkau. Di KUA Kecamatan Pudak jumlah peristiwa nikah perbulannya dibawah 50 peristiwa, di KUA Sooko untuk jumlah peristiwa nikah perbulan adalah dibawah 50 perbulannya begitupun dengan KUA Kecamatan Ngrayun. Disini bisa ditentukan untuk tipologi ke tiga KUA tersebut yaitu termasuk dalam tipologi C. Namun jika dikaitkan dengan keadaan geografis yang cukup sulit atau berada dalam daerah perbatasan, pegunungan dan pinggiran seharusnya ke tiga KUA tersebut masuk dalam tipologi D1, hal ini sesuai dengan apa yang telah disebutkan dalam Peraturan Menteri Agama No. 46 tahun 2014 tersebut yaitu: Tipologi D1, KUA Kecamatan yang secara geografis berada di daerah terluar, terdalam dan di daerah perbatasan daratan.

\section{Penutup}

${ }^{25}$ Bimasislam.kemenag.go.id/post/opini/pp-48-2014, diakses tgl. 25 September 2019, Pukul 10.25 wib. 
Pelaksanaan nikah di Kecamatan Pudak, Sooko dan Ngrayun sudah sesuai PMA NO. 46 tahun 2014 tersebut. Penentuan biaya nikah di KUA kecamatan Pudak, Sooko dan Ngrayun walaupun kondisi geografisnya sangat berbeda dengan kondisi wilayah yang lainya tetap disamakan yaitu Rp 600.000,00 (enam ratus ribu rupiah) dan sudah sesuai dengan PP 48 tahun 2014. Untuk tipologi KUA Kecamatan, bahwa KUA Kecamatan Pudak, Sooko dan Ngrayun masuk dalam kategori tipologi C.

\section{Daftar Pustaka}

Abdurrahman. 2010. Kompilasi Hukum Islam di Jakarta. Jakarta: CV. Akademika Pressindo.

Ahmad Saebani, Beni dan Syamsul Falah. 2011. Hukum Perdata Islam di Indonesia. Bandung: CV. Pustaka Setia.

Ahmad Saebani,Bani. 2008. Perkawinan Dalam Hukum Islam dan Undang-undang. Bandung: Pustaka Setia.

Al Hamdani,H.S.A. 2002. Risalah Nikah (Hukum Perkawinan Islam). Jakarta: Pustaka Amani.

Al-Qur'an \& Tejemahannya. 1995. Semarang: PT. Karya Putra.

Amin Summa,Muhammad. 2004. Hukum Keluarga Islam di Dunia Islam. Jakarta: PT. Raja Grafindo Perkasa.

Bidang Urusan Agama Islam Kantor Wilayah Departemen Agama Provinsi Jawa Timur, 2007. Himpunan Seputar Kepenghuluan. Surabaya: Departemen Agama Jawa Timur.

Bimasislam.kemenag.go.id/post/opini/pp-48-2014, diakses tgl. 25 September 2019, Pukul 10.25 wib.

Hamid, Zahry. 1976. Pokok-Pokok Hukum Perkawinan Islam dan Undang-Undang Perkawinan di Indonesia. Yogyakarta: Binacipta.

Idris Ramulyo, Mohd. 1999. Hukum Perkawinan Islam. Jakarta: Bumi Aksara.

Keputusan Dirjen Bimbingan Masyarakat Islam No. 748 tahun 2014 tentang PNBP, pdf. diakses pada tanggal 19 September 2019, jam 19.30 WIB.

Manan, Abdul. 2006. Aneka Masalah Hukum Perdata Islam di Indonesia. Jakarta: Kencana Prenada Media Group.

Peraturan Pemerintah No. 47 Tahun 2004. Pdf. diakses pada tanggal 18 September 2019, Pukul 20.45 WIB.

Peraturan Pemerintah No. 48 Tahun 2014. Pdf. diakses pada tanggal 20 September 2019, Pukul 19.25 WIB.

Rahman Ghazaly, Abd. Fiqh Munakahad. 2003. Jakarta: Kencana Prenada Media.

Team Nusantara. 2009. Kitab Undang-undang Hukum Perdata (Burgerlijk Wetbook).Jakarta: Nusantara Publisher.

Undang-Undang Nomor 1 tahun 1974 tentang Perkawinan, pdf. diakses tanggal 19 September 2019, Pukul 21.10 WIB. 